\title{
Two new and a known species of the genus Oriverutus Siddiqi, 1971 (Nematoda: Dorylaimida) from Japan
}

\author{
Wasim Ahmad ${ }^{1}$ and Masaaki Araki ${ }^{2}$
}

\begin{abstract}
Two new and a known species of the genus Oriverutus Siddiqi, 1971 is described and illustrated. Oriverutus arcuicaudatus $\mathrm{sp}$. n. is characterized by having $0.61-0.71 \mathrm{~mm}$ long body; lip region distinctly offset with protruding labial papillae; $16-17 \mu \mathrm{m}$ long, attenuated odontostyle; amphidelphic gonad with unsclerotized pars refringens vaginae; a small postrectal sac; ventrally arcuate tail and male with a single ventromedian supplement. $O$. parvus sp. n. has $0.65-0.71 \mathrm{~mm}$ long body; lip region slightly offset with prominent labial papillae; 13-14 $\mu \mathrm{m}$ long, attenuated odontostyle; amphidelphic gonad with sclerotized pars refringens vaginae and elongate conoid, slightly dorsally bent tail. $O$. occidentalis Peña Santiago and Peralta, 1995 is reported here for the first time from Japan. Jpn. J. Nematol. 32 (2), 31-44 (2002).
\end{abstract}

Key words: taxonomy, description, new species, new record, dorylaim nematodes.

During the course of study on species diversity of free-living soil-inhabiting nematodes in Japan, soil samples collected from various localities yielded three populations of nematodes belonging to the genus Oriverutus Siddiqi, 1971. On detailed study, they were found to represent two new and a known species which are being described and illustrated in the following.

\section{MATERIALS AND METHODS}

The nematodes were extracted from soil samples by Cobb's sieving method and centrifugal sugarflotation technique. Nematodes obtained in clear water were killed in hot water and fixed in TAF. Fixed nematodes were dehydrated by Seinhorst's rapid glycerine method and mounted on slides in anhydrous glycerine. Measurements were done using an ocular micrometer and drawings were made using a drawing tube attached to the microscope.

\section{DESCRIPTIONS}

\section{Oriverutus arcuicaudatus sp. $\mathbf{n}$.}

(Figs. 1 and 2)

Measurements: Table 1

Nematology and Soil Zoology Unit, National Institute for Agro-Environmental Sciences, 3-1-3 Kannondai Tsukuba, Ibaraki 305-8604, Japan.

${ }^{1}$ JSPS Fellow from Aligarh Muslim University, India.

${ }^{2}$ To whom all correspondence should be addressed. 


\section{Description:}

Female: Body slightly curved ventrad upon fixation, tapering towards both the extremities. Cuticle finely striated, 1.5-2. $0 \mu \mathrm{m}$ thick at mid body and 3-4 $\mu \mathrm{m}$ on tail. Lateral chords about one-third of body width at mid body. Lateral, dorsal and ventral body pores indistinct.

Lip region offset by constriction, wider than the adjoining body, about 2.2-2.4 times as wide as high and about half as wide as body width at neck base. Lips separate; labial papillae distinctly projecting above lip contour. Amphids large; fovea stirrup-shaped, their aperture occupying almost entire lateral surface at that level; fusus large, at $22-24 \mu \mathrm{m}$ behind the amphideal aperture. Odontostyle attenuated, 1.25 times the width of lip region; its aperture about one-fifth of its length. Guiding ring single, at 0.49 0.54 lip region width from anterior end. Odontophore rod-like, about 1.4 times the odontostyle length. Nerve ring situated at about $39-41 \%$ of neck length from anterior end. Pharyngeal expansion gradual; expanded part highly granular, occupying about $38-41 \%$ of total neck length. Cardia short, conoid with

Table 1. Measurements of Oriverutus arcuicaudatus sp. n. (all measurements in $\mu \mathrm{m}$ )

\begin{tabular}{|c|c|c|c|}
\hline Characters & Holotype female & $\begin{array}{c}\text { Paratype } \\
\text { females } n=2\end{array}$ & $\begin{array}{c}\text { Paratype } \\
\text { males } n=3 \text { (mean) }\end{array}$ \\
\hline Body length & 648 & $645-710$ & 615-701 (655) \\
\hline Body width at pharynx base & 27.0 & $28.0-28.5$ & $24-26(25.5)$ \\
\hline mid body & 28 & 29 & $24-27(26)$ \\
\hline anus & 19.6 & $17.8-18.5$ & $18.5-19.5$ \\
\hline $\mathrm{a}$ & 23.0 & $22.0-24.5$ & $25-26$ \\
\hline $\mathrm{b}$ & 3.2 & $3.1-3.3$ & $3.0-3.4(3.2)$ \\
\hline $\mathrm{c}$ & 15.8 & $18.5-19.7$ & $16.9-18.7(17.5)$ \\
\hline$c^{\prime}$ & 2.1 & $1.9-2.0$ & $1.9-2.0(1.9)$ \\
\hline $\mathrm{V}$ & 55.0 & $53.0-54.5$ & - \\
\hline G 1 & 15 & $15-17$ & - \\
\hline G 2 & 17 & $14-16$ & - \\
\hline Lip region width & 12.7 & $12.0-12.7$ & 12.7 \\
\hline Lip region height & 5.7 & 5.0 & $5.7-6.4$ \\
\hline Amphid aperture & 7.0 & $7.0-8.0$ & $7-8$ \\
\hline Odontostyle length & 16 & $16-17$ & $16.0-16.5$ \\
\hline Guiding ring from ant. End & 6.3 & $6.3-6.9$ & $6.3-6.9$ \\
\hline Odontophore length & 18.4 & $18.0-19.0$ & $17.0-18.5$ \\
\hline Nerve ring from ant. End & 82 & 83-84 & $80-84(82)$ \\
\hline Neck length & 201 & $209-216$ & $193-205(201)$ \\
\hline Expanded part of pharynx & 81 & $84-88$ & $74-85(78)$ \\
\hline Cardia length & 7.0 & $7.0-8.0$ & $6.5-7.0$ \\
\hline Anterior genital branch & 96 & $92-119$ & - \\
\hline Posterior genital branch & 113 & $99-107$ & - \\
\hline Vulva from ant. End & 355 & $352-377$ & - \\
\hline Vagina length & 16 & $14-15$ & - \\
\hline Prerectum length & 20 & $20-31$ & $22-38(30)$ \\
\hline Rectum length & 18 & $17-18$ & $17-19(18)$ \\
\hline Tail length & 41 & $35-36$ & $36-38(37)$ \\
\hline Spicules length & - & - & $25.5-27.0(26)$ \\
\hline Lateral guiding piece length & - & - & 6.5 \\
\hline Ventromedian supplement & - & - & 1 \\
\hline Copulatory muscles & - & - & 13 \\
\hline Sperms & - & - & $7-8$ \\
\hline
\end{tabular}




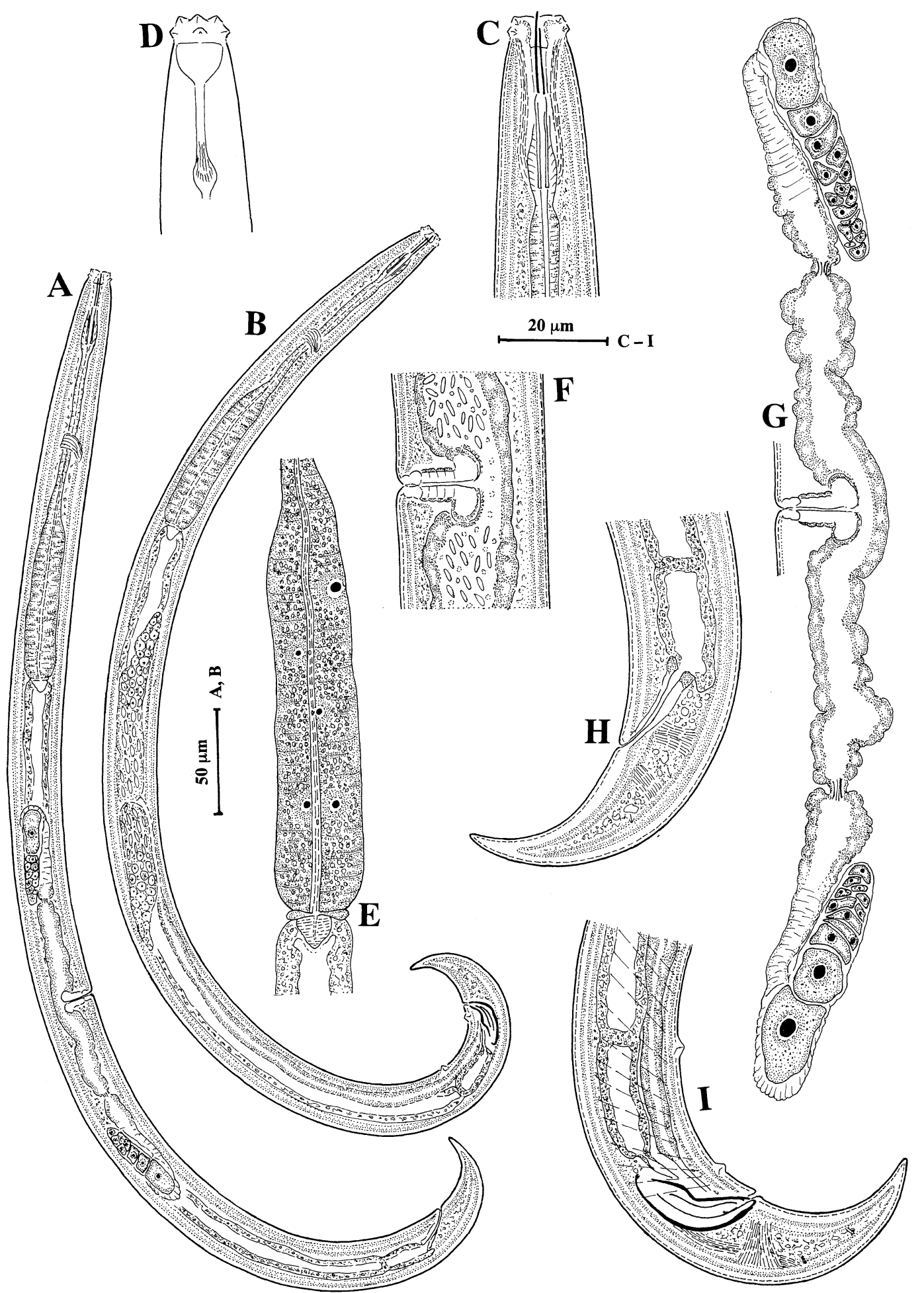

Fig. 1. Oriverutus arcuicaudatus sp. n. A: Entire female; B: Entire male; C: Anterior region; D: Anterior end showing amphid; E: Expanded part of pharynx; F: Vulval region; G: Female genital tract; H: Female posterior region; I: Male posterior region. 

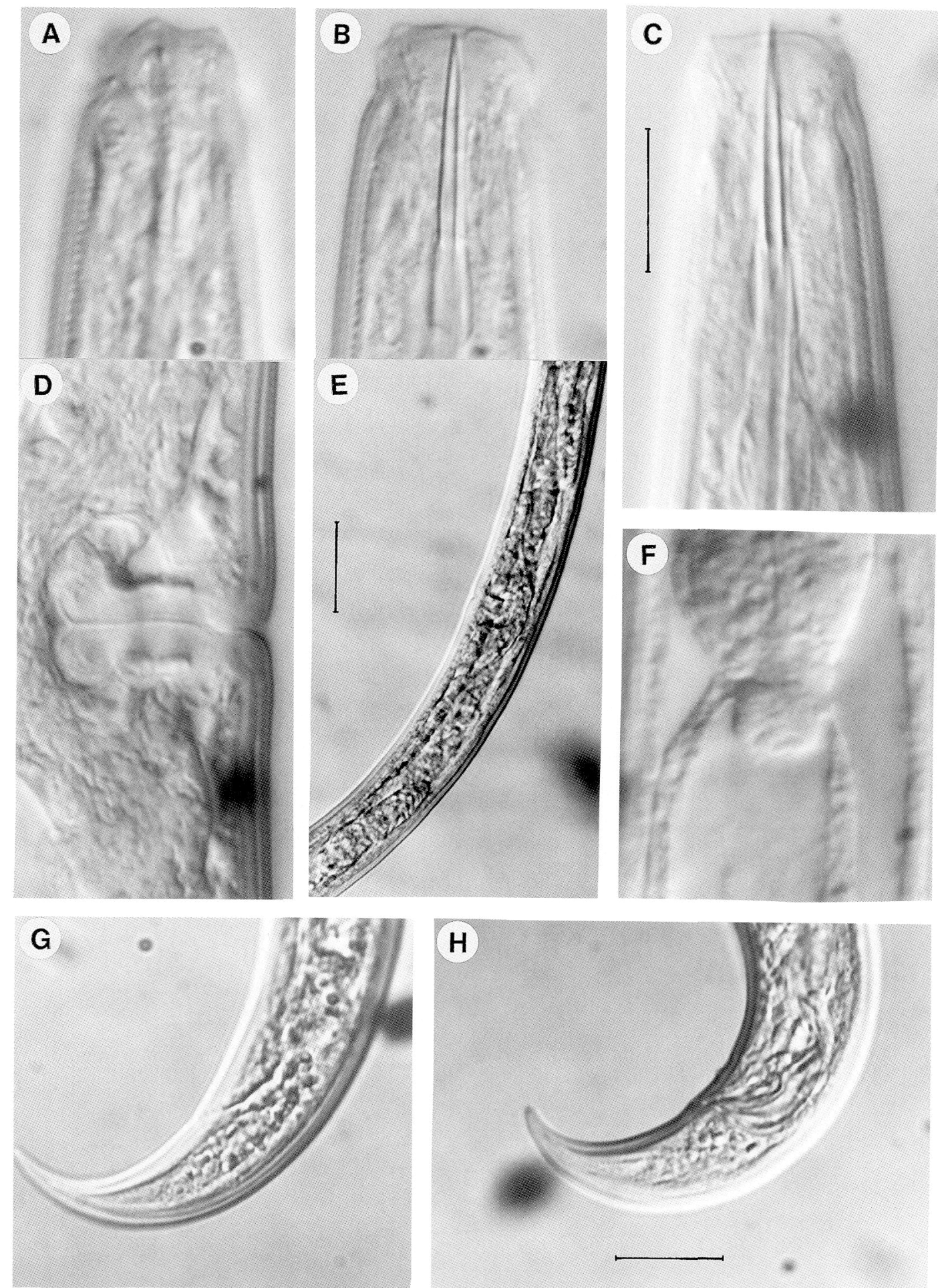

Fig. 2. Oriverutus arcuicaudatus sp. n. A-C: Anterior region; D: Vulval region; E: Female genital tract; F: Pharyngeointestinal junction; G: Female posterior end; H: Male posterior end (Scale bars: A-D, F $=10 \mu \mathrm{m} ; \mathrm{E}=30 \mu \mathrm{m}, \mathrm{G}$, $\mathrm{H}=20 \mu \mathrm{m})$. 
weakly developed, somewhat disc-like glandular tissue. Pharyngeal gland nuclei and their orifices are located as follows:

$$
\begin{array}{lll}
\text { DO }=64-65 & \mathrm{~S}_{1} \mathrm{~N}_{1}=76-77 & \mathrm{~S}_{2} \mathrm{~N}=86-88 \\
\mathrm{DN}=74-75 & \mathrm{~S}_{1} \mathrm{~N}_{2}=82-83 & \mathrm{~S}_{2} \mathrm{O}=88-90 \\
\text { DO-DN }=9-10 & &
\end{array}
$$

Reproductive system amphidelphic; both the sexual branches equally developed. Ovaries reflexed, measuring 38-49 $\mu \mathrm{m}$ (anterior) and 39-50 $\mu \mathrm{m}$ (posterior) with oocytes arranged in a single row except near the tip. Oviduct joining ovary subterminally, 43-45 $\mu \mathrm{m}$ (anterior) and 40-49 $\mu \mathrm{m}$ (posterior) long with distinct pars dilatata. Uterus a wide tube, measuring 38-47 $\mu \mathrm{m}$ (anterior) and 48-50 $\mu \mathrm{m}$ (posterior). Sphincter present at oviduct-uterus junction. Vulva transverse; vagina thick walled with circular musculature; pars refringens vaginae unsclerotized. Prerectum short, about one anal body width long with a small post-rectal sac. Rectum about one anal body width long. Tail elongate-conoid, ventrally arcuate, 1.9-2. 1 anal body widths long, with a pair of caudal pore on each side.

Male: Similar to females in general morphology, except for slightly more curved posterior region because of the presence of copulatory muscles. Supplements, consisting of an adanal pair and a single ventromedian at $26-29 \mu \mathrm{m}$ from the adanal pair. Spicules dorylaimoid, about 1.4 times anal body widths long. Lateral guiding pieces about one-fourth of spicule length. Prerectum about 1.1-1.4 anal body widths long, terminating at level with the ventromedian supplement. Rectum about one anal body width long. Tail similar to female, about 1.9 anal body widths long with a pair of caudal pore on each side.

Type habitat and locality: Soil around roots of forest trees from temperate deciduous forest, Ogawa Forest Reserve, Kitaibaraki City, Ibaraki Prefecture, Japan.

Type material: Holotype female slide no. JNC/NIAES/ 0001-01 was obtained from soil samples collected on 17-XI-2000 at the type locality by the second author together with paratype female slide no. JNC/NIAES/ 0001-02 and males JNC/NIAES/ 0001-03 and JNC/NIAES/ 0001-04. A paratype female JNC/NIAES/ 0001-05 and a male JNC/NIAES/ 0001-06 was further obtained from soil sample collected on 13. VIII. 2002 from the same locality. All the specimens are deposited in the nematode collection of the Nematology and Soil Zoology Unit, National Institute for Agro-Environmental Sciences.

Diagnosis and Relationships: Oriverutus arcuicaudatus sp. n. is characterized by having small sized body $(\mathrm{L}=0.61-0.71 \mathrm{~mm})$; lip region distinctly offset with protruding labial papillae; $16-17 \mu \mathrm{m}$ long, attenuated odontostyle; large amphids; amphidelphic gonad with unsclerotized pars refringens vaginae; a small post-rectal sac; ventrally arcuate tail and males with only one ventromedian supplement.

In the shape of lip region and the presence of post-rectal sac, the new species has resemblance with O. sundarus (Williams, 1964) Siddiqi, 1971 and O. anisi Ahmad \& Jairajpuri, 1987. However, it distinctly differs from $O$. sundarus in being didelphic (vs. mono-opisthodelphic). From $O$. anisi, the new species differs in being smaller and comparatively robust (vs. $\mathrm{L}=1.11 \mathrm{~mm}$; $\mathrm{a}=29-32$ ); shorter odontostyle and odontophore (vs. odontostyle $18 \mu \mathrm{m}$; odontophore $21 \mu \mathrm{m}$ ); less c ratio in female (vs. c = 23); shorter prerectum (vs. prerectum $37 \mu \mathrm{m}$ ); in the absence of vaginal sclerotization (vs. distinct vaginal sclerotization); smaller spicules (vs. spicules $33 \mu \mathrm{m}$ ) and in the number of ventromedian supplements (vs. ventromedian supplements 6$)$.

In the presence of an arcuate tail, the new species has resemblance with $O$. arcuatus Baqri, 1980, but differs from it, in addition to being smaller and robust (vs. $\mathrm{L}=0.8 \mathrm{~mm}$; $\mathrm{a}=33$ ); has longer odonto- 
style (vs. odontostyle 13-14 $\mu \mathrm{m}$ ); posterior vulva (vs. V = 50); longer spicules (vs. spicules $22 \mu \mathrm{m}$ ) and fewer ventromedian supplements (vs. ventromedian supplements 3 ).

\section{Oriverutus parvus sp. n.}

Measurements: Table 2

(Figs. 3 and 4)

\section{Description:}

Female: Body slightly curved ventrad upon fixation, tapering towards both the extremities. Cuticle finely striated, 1.5-2. $0 \mu \mathrm{m}$ thick at mid body and 3-4 $\mu \mathrm{m}$ on tail. Lateral chords about one-third of body width at mid body. Lateral, dorsal and ventral body pores indistinct.

Lip region slightly offset, about 1.9-2.2 times as wide as high and about one-third as wide as body width at neck base; labial papillae protruding above labial contour. Amphids with stirrup-shaped fovea; their aperture occupying about two-third of the corresponding body width; fusus 18-19 $\mu \mathrm{m}$ behind amphideal aperture. Odontostyle attenuated, 1.2-1.3 times the width of lip region; its aperture about one-

Table 2. Measurements of Oriverutus spp. (all measurements in $\mu \mathrm{m}$ )

\begin{tabular}{|c|c|c|c|}
\hline \multirow[b]{2}{*}{ Characters } & \multicolumn{2}{|c|}{ Oriverutus parvus sp. $\mathrm{n}$} & \multirow{2}{*}{$\begin{array}{c}\text { O. occidentalis } \\
\text { Females } \\
\mathrm{n}=2\end{array}$} \\
\hline & Holotype female & $\begin{array}{c}\text { Paratype } \\
\text { females, } \mathrm{n}=2\end{array}$ & \\
\hline Body length & 669 & $655-719$ & $939-963$ \\
\hline Body width at pharynx base & 30 & $32-35$ & $29-30$ \\
\hline mid body & 33 & $33-36$ & $30-31$ \\
\hline anus & 20 & $20-21$ & 21 \\
\hline $\mathrm{a}$ & 22 & $20-21$ & $31-33$ \\
\hline $\mathrm{b}$ & 3.2 & $3.19-3.24$ & 3.4 \\
\hline $\mathrm{c}$ & 17.3 & $17.7-18.6$ & $18.2-19.5$ \\
\hline$c^{\prime}$ & 1.96 & $1.85-1.87$ & $2.3-2.5$ \\
\hline $\mathrm{V}$ & 54 & 55 & $43.6-43.7$ \\
\hline G 1 & 12 & 12 & - \\
\hline G 2 & 12 & $12-14$ & $10-12$ \\
\hline Lip region width & 10.0 & $10-11$ & 12 \\
\hline Lip region height & 5.0 & $5.0-5.7$ & 4.5 \\
\hline Amphid aperture & 8.5 & $8.0-8.5$ & $8-9$ \\
\hline Odontostyle length & 13.0 & $13-14$ & $18-20$ \\
\hline Guiding ring from ant. End & 5.7 & 6.5 & 5.7 \\
\hline Odontophore length & 16.5 & $17-18$ & $18-19$ \\
\hline Nerve ring from ant. End & 89.5 & $86-89$ & $116-124$ \\
\hline Neck length & 206 & $205-222$ & $274-281$ \\
\hline Expanded part of pharynx & 81 & $83-94$ & $110-116$ \\
\hline Cardia length & 9.5 & $9.5-10.5$ & $9.5-10.0$ \\
\hline Anterior genital branch & 81 & $81-86$ & - \\
\hline Posterior genital branch & 83 & $88-91$ & $92-120$ \\
\hline Vulva from ant. End & 363 & $361-393$ & $411-420$ \\
\hline Vagina length & 15 & $15-16$ & $15-17$ \\
\hline Prerectum length & 45 & $40-58$ & $55-96$ \\
\hline Rectum length & 18 & $18-20$ & $18-19$ \\
\hline Tail length & 39 & $37-39$ & $48-53$ \\
\hline
\end{tabular}



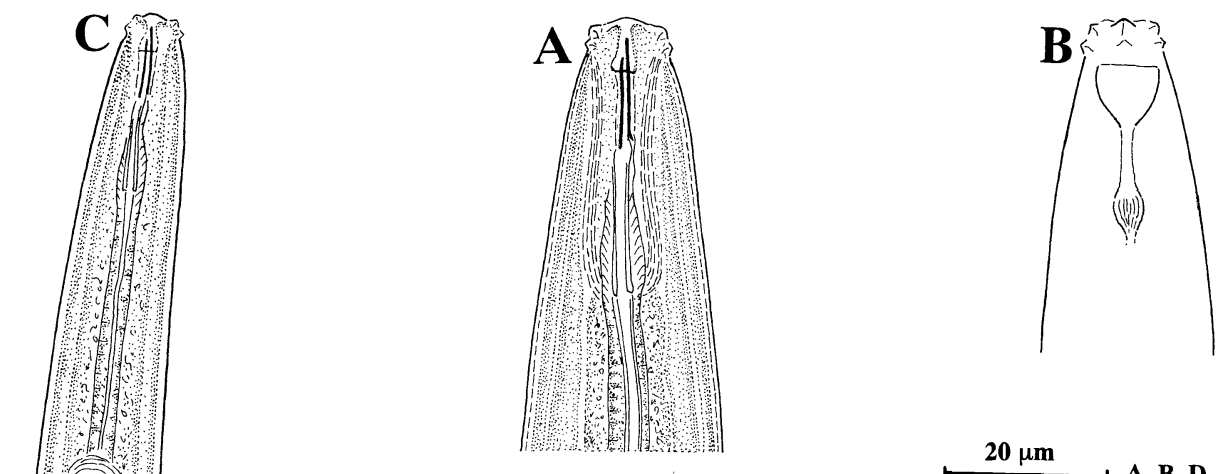

$20 \mu \mathrm{m}$

A, B, D - H
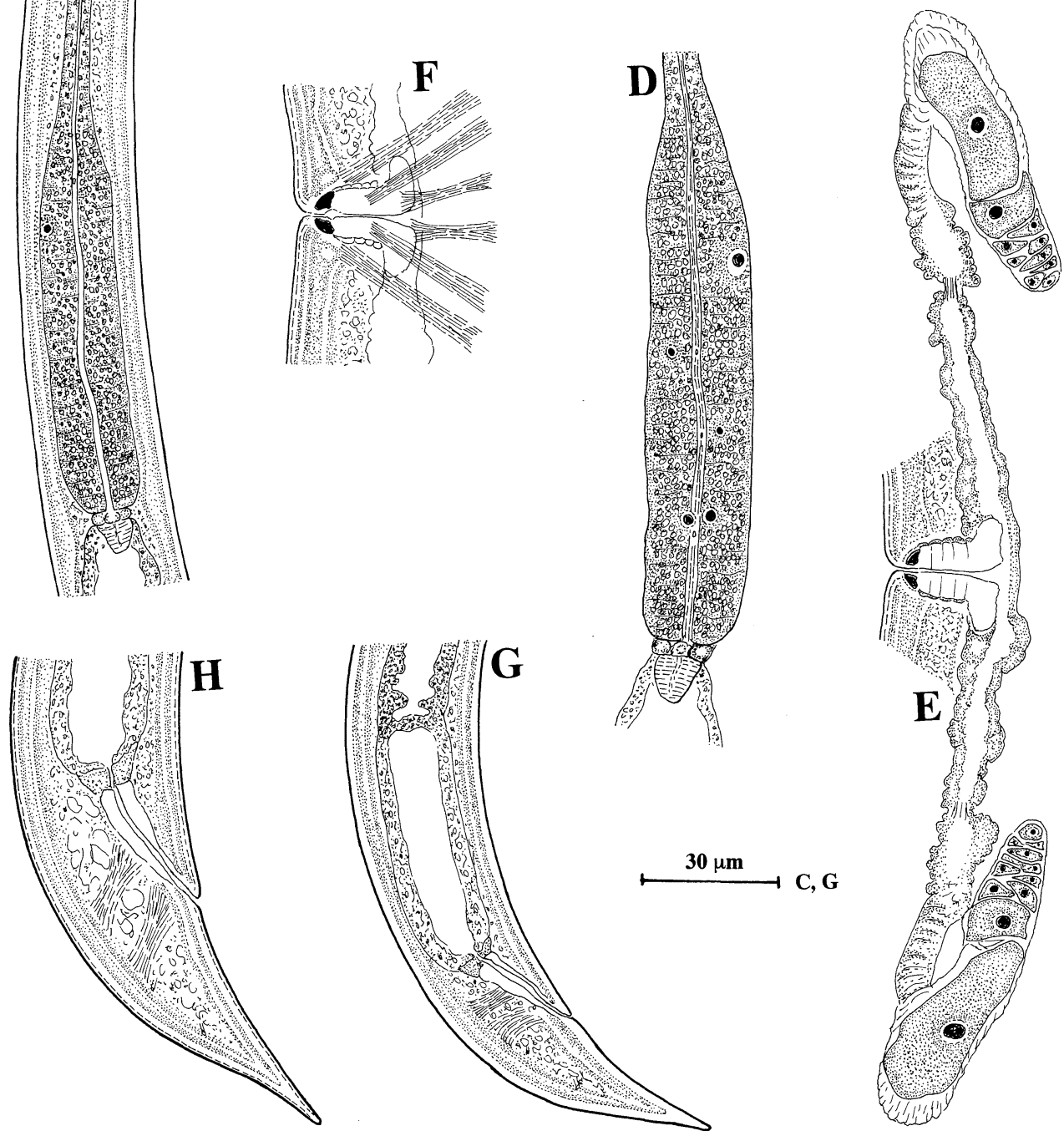

Fig. 3. Oriverutus parvus sp. n. A: Anterior region; B: Anterior end showing amphid; C: Pharyngeal region; D: Expanded part of pharynx; E: Female genital tract; F: Vulval region; G: Female posterior region; H: Female posterior end. 

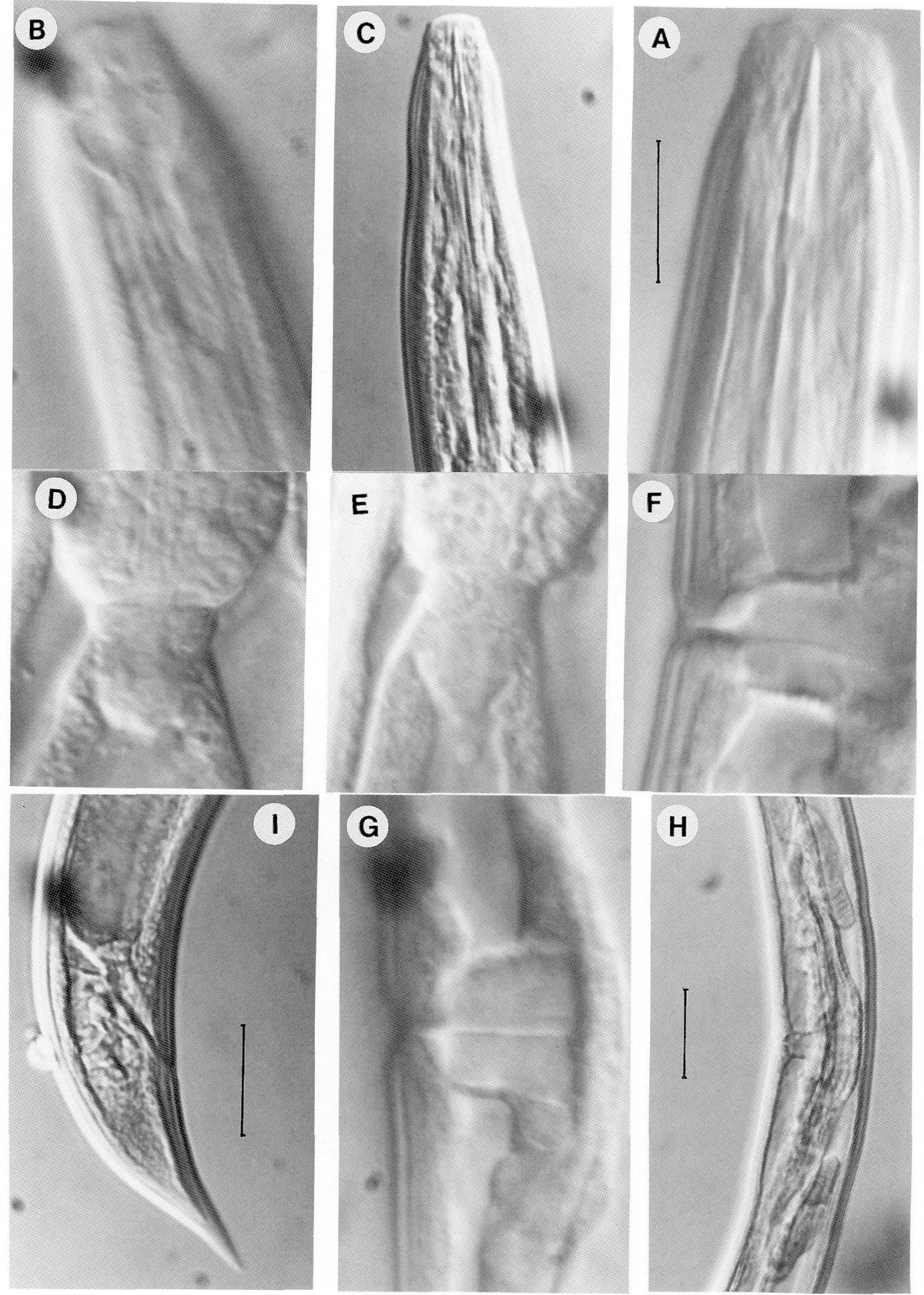

Fig. 4. Oriverutus parvus sp. n. A-C: Anterior region; D-E: Pharyngeo-intestinal junction; F-G: Vulval region; H: Female genital tract; I: Female posterior end (Scale bars: A, B, D-G $=10 \mu \mathrm{m} ; \mathrm{C}, \mathrm{I}=20 \mu \mathrm{m}, \mathrm{H}=30 \mu \mathrm{m}$ ). 
fourth of its length. Guiding ring single, at 0.55-0.59 lip region width from anterior end. Odontophore rod-like, about 1.35-1.45 times the odontostyle length. Nerve ring situated at about $40-43 \%$ of neck length from anterior end. Pharyngeal expansion gradual; expanded part highly granular, occupying about $39-42 \%$ of total neck length. Cardia short, conoid; glandular organ present at pharyngeo-intestinal junction. Pharyngeal gland nuclei and their orifices are located as follows:

$$
\begin{array}{lll}
\text { DO }=62-65 & \mathrm{~S}_{1} \mathrm{~N}_{1}=74-75 & \mathrm{~S}_{2} \mathrm{~N}=87-88 \\
\mathrm{DN}=69-70 & \mathrm{~S}_{1} \mathrm{~N}_{2}=82-83 & \mathrm{~S}_{2} \mathrm{O}=88-89 \\
\text { DO-DN }=5.8-6.8 & &
\end{array}
$$

Reproductive system amphidelphic; both the sexual branches equally developed. Ovaries reflexed, measuring 44-51 $\mu \mathrm{m}$ (anterior) and 44-56 $\mu \mathrm{m}$ (posterior), with oocytes arranged in a single row except near the tip. Oviduct joining ovary subterminally, 28-32 $\mu \mathrm{m}$ (anterior) and 31-35 $\mu \mathrm{m}$ (posterior) long. Uterus a straight tube, measuring 35-38 $\mu \mathrm{m}$ (anterior) and 35-36 $\mu \mathrm{m}$ (posterior). Sphincter present at oviduct-uterus junction. No trace of sperms either in uterus or oviduct. Vulva transverse; vagina thickwalled with circular musculature; pars refringens vaginae with distinct triangular cuticularized pieces. Prerectum 2. 0-2. 8 anal body widths long. Rectum about one anal body width long. Tail elongate conoid, almost straight to slightly dorsally bent with a pair of caudal pores on each side.

\section{Male: Not found}

Type habitat and locality: Soil around roots of forest trees from evergreen forest; Mt. Hinokuma, Kanzaki Town, Saga prefecture, Japan.

Type material: Holotype female slide no. JNC/NIAES/ 0002-01 was obtained from soil samples collected on 8 -VIII-2000 by Dr. A. L. Bilgrami at the type locality together with paratype females slide nos. JNC/NIAES/ 0002-02 and JNC/NIAES/ 0002-03. All the specimens are deposited in the nematode collection of the Nematology and Soil Zoology Unit, National Institute for Agro-Environmental Sciences.

Diagnosis and Relationships: Oriverutus parvus sp. n. is characterized by having small sized body $(\mathrm{L}=0.65-0.71 \mathrm{~mm})$; lip region slightly offset with prominent labial papillae; $13-14 \mu \mathrm{m}$ long, attenuated odontostyle; amphidelphic gonad with sclerotized pars refringens vaginae and elongate conoid, slightly dorsally bent tail.

The new species closely resembles O. hastus Ahmad and Jairajpuri, 1982 and O. parahastus Ahmad and Siddiqi, 1997 in the shape of lip region and general morphology. However, it differs from $O$. hastus in being smaller and robust (vs. $\mathrm{L}=0.89-0.93 \mathrm{~mm}$; $\mathrm{a}=30-44$ ); the shape of lip region and amphid (vs. lip region distinctly narrower than the adjoining body and amphids bell-shaped); more posterior vulva (vs. V = 49-50) and shorter tail (vs. tail 46-49 $\mu \mathrm{m}$ ).

From $O$. parahastus, the new species differs in addition to being smaller and robust (vs. $\mathrm{L}=0.71$ $0.75 \mathrm{~mm} ; \mathrm{a}=24-29$ ); in the shape of lip region (vs. lip region narrow and almost continuous with the body); smaller odontostyle and odontophore (vs. odontostyle 18-23 $\mu \mathrm{m}$; odontophore 21-23 $\mu \mathrm{m}$ ); comparatively less V-value (vs. V = 59-60) and shorter tail (vs. tail 65-75 $\mu \mathrm{m} ; \mathrm{c}=9.7-11.4 ; \mathrm{c}^{\prime}=4.0-4.6$ ).

\section{Oriverutus occidentalis Peña Santiago and Peralta, 1995}

(Figs. 5 and 6)

Measurements: Table 2 

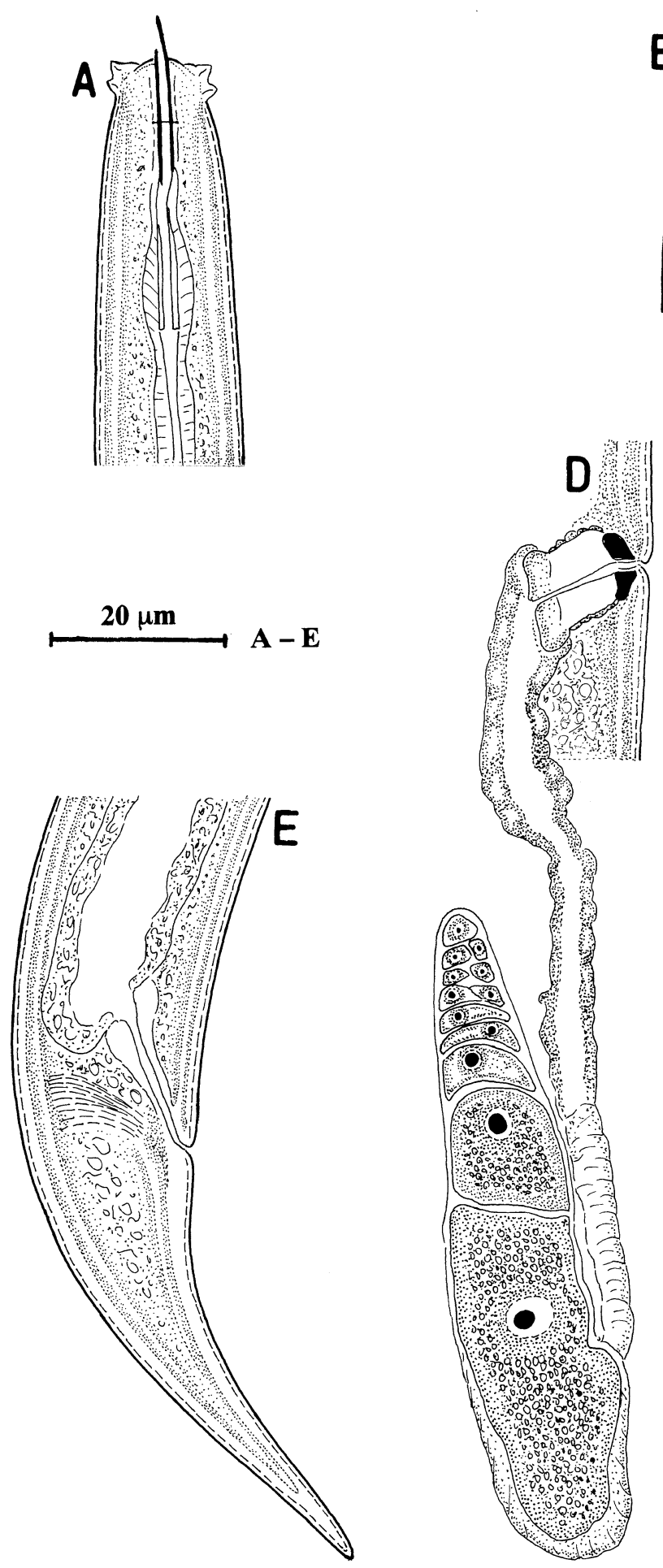

C

Fig. 5. Oriverutus occidentalis Peña Santiago and Peralta, 1995. A: Anterior region; B: Anterior end showing amphid; C: Expanded part of pharynx; D: Female genital tract; E: Female posterior end. 

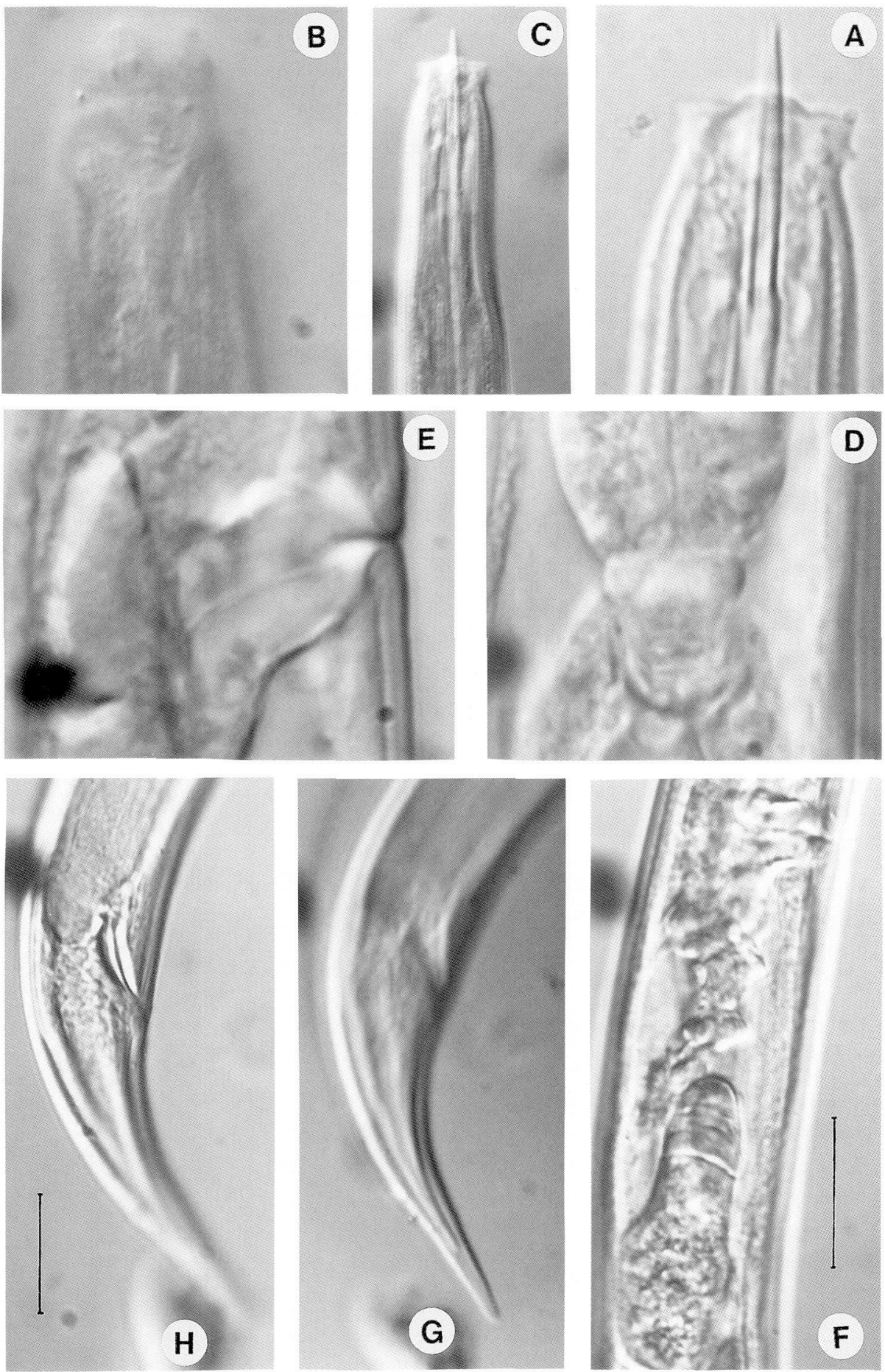

Fig. 6. Oriverutus occidentalis Peña Santiago and Peralta, 1995. A-C: Anterior end; D: Pharyngeo-intestinal junction; E: Vulval region; F: Female genital tract; G-H: Female posterior region (Scale bars: A, B, D-F = $10 \mu \mathrm{m} ; \mathrm{C}, \mathrm{G}, \mathrm{H}=20 \mu \mathrm{m}$ ). 


\section{Description:}

Female: Body slightly curved ventrally upon fixation, tapering towards both the extremities. Cuticle finely striated, 1.5-2.0 $\mu \mathrm{m}$ thick at mid body and 3-4 $\mu \mathrm{m}$ on tail. Lateral chords about one-third of body width at mid body. Lateral, dorsal and ventral body pores indistinct.

Lip region distinctly offset from the body by a deep constriction, about 2.7 times as wide as high and about two-fifth as wide as body width at neck base. Lips separate, lobe-like with papillae distinctly projecting above labial contour. Amphids stirrup-shaped; their aperture occupying about two-third of the corresponding body width. Odontostyle long, attenuated, about 1.6 times as long as lip region width. Guiding ring single, at 0.5 lip region width from anterior end. Odontophore rod-like, about 0.9 times the odontostyle length. Nerve ring situated at $42-44 \%$ of neck length from anterior end. Pharyngeal expansion gradual; expanded part occupying about $39-42 \%$ of total neck length. Cardia short, conoid. Distinct glandular tissue present at pharyngeo-intestinal junction. Pharyngeal gland nuclei and their orifices are located as follows:

$$
\begin{array}{lll}
\text { DO }=60-61 & \mathrm{~S}_{1} \mathrm{~N}_{1}=70-72 & \mathrm{~S}_{2} \mathrm{~N}=88-89 \\
\mathrm{DN}=63-64 & \mathrm{~S}_{1} \mathrm{~N}_{2}=77-78 & \mathrm{~S}_{2} \mathrm{O}=89-90 \\
\text { DO-DN }=3-4 & &
\end{array}
$$

Reproductive system mono-opisthodelphic. Ovary reflexed, measuring 51-79 $\mu \mathrm{m}$ with oocytes arranged in a single row except near tip. Oviduct joining ovary subterminally, $41-54 \mu \mathrm{m}$ long. Uterus measuring 31-38 $\mu \mathrm{m}$. Sphincter present at oviduct uterus junction. Anterior uterine branch completely absent. Vulva transverse. Vagina posteriorly directed; pars refringens vaginae with distinct triangular cuticularized pieces. Prerectum 2.7-4.5 anal body widths long. Tail elongate conoid with slightly dorsally bent tip.

\section{Male: Not found}

Habitat and localitry: Soil around roots of forest trees from evergreen forest; Mt. Hinokuma, Kanzaki Town, Saga Prefecture, Japan.

Remarks: Peña Santiago and Peralta (1995) described O. occidentalis from Oriental Spain and incidently this was the first report of an Oriverutus species from Europe. The present population of $O . o c$ cidentalis from Japan is quite similar to one described from Spain except for being slightly smaller in size (vs. $\mathrm{L}=1.08-1.26 \mathrm{~mm}$ in the type specimens) and comparatively shorter tail although the $\mathrm{c}$ and c' ratios are within the range. In the original description Peña Santiago and Peralta described cardiac cells as being obscure, but in our present specimens from Japan the cardiac tissue is well developed which is a characteristic feature of majority of Oriverutus species. These differences have been considered here as geographical variations and the two specimens are here identified as O. occidentalis.

\section{DISCUSSION}

The genus Oriverutus Siddiqi, 1971, is at present represented by 20 species which have mainly been reported from India, Angola, Mauritius, Samoa, Nigeria, Cameroon, Ivory Coast, Colombia and Mexico. The first author also recently collected several populations of Oriverutus species from Costa Rica, Nicaragua and New Zealand (unpublished). Except for $O$. occidentalis all the other species so far reported are from tropical climate. The present three species from temperate climate in Japan, one of which has al- 
ready been earlier reported from Europe, is of biogeographical importance and there is a possibility that more species of this group exists in temperate climate and would be recorded in future.

\title{
ACKNOWLEDGMENTS
}

The first author is thankful to the Japanese Society for Promotion of Science for extending invitation as Visiting Fellow of the Society to carry out research at the National Institute for AgroEnvironmental Sciences.

\section{LITERATURE CITED}

Ahmad, W. and Jairajpuri, M. S. (1982) Some new and known species of Dorylaimoidea. Nematologica 28, 3961.

Ahmad, W. and Jairajpuri, M. S. (1987) Studies on the genus Oriverutus (Nematoda: Dorylaimida). Nematologica 33, 10-21.

Ahmad, W. and Siddiqi, M. R. (1997) Four new and one known species of Oriverutus Siddiqi (Dorylaimida) from tropical rain forests. International Journal of Nematology 7, 182-189.

Baqri, Q. H. (1980) Two new species of Dorylaimidae (Dorylaimida: Nematoda) from Tamil Nadu, India. Bulletin of the Zoological Survey of India 2, 139-141.

Peña Santiago, R. and Peralta, M. (1995) Nematodes of the Order Dorylaimida from Andalucia, Oriental Spain. Oriverutus occidentalis sp. $\mathrm{n}$. and a compendium of the genus. Afro-Asian Journal of Nematology 5, 204208.

Siddiqi, M. R. (1971) Oriverutus lobatus gen. n., sp. n. and Sicaguttur sartum gen. n., sp. n. (Nematoda: Dorylaimoidea) from cultivated soil in Africa. Nematologica 16, 483-491.

Williams, J. R. (1964) Studies on the nematode soil fauna of sugar cane fields in Mauritius. 6. Eudorylaimus sundarus $\mathrm{n}$. sp. (Dorylaimidae). Nematologica 10, 319-322.

Received August 29, 2002.

\section{和文摘要}

\section{ドリライミダ目土畩線虫 Oriverutus 属の本邦産 2 新種および 1 既知種の記載}

\author{
Wasim Ahmad・荒城 雅昭
}

これまでに収集した本邦産 Oriverutus 属線虫標本について精査したところ、2 新種および 1 本邦未記録種が含まれていることが判明したので、これらの記載、図示を行った。新種 Oriverutus arcuicaudatus は、体長0.61〜0.65 mm で、唇乳頭が突出して口唇部が顕著に区別されるこ と、歯針は細く長さが15～16 $16 \mathrm{~m}$ あること、雌性生殖腺は両卵巣型で、陰門環 (pars refringens vaginae）は骨化しないこと、直腸囊（post-rectal sac）は小さいこと、尾部が腹側に曲ること、 
雄では、前腹部補助器（ventromedian supplement）が1個であることなどで特徴付けられる。 新種 $O$. parvus は、体長 $0.65 \sim 0.71 \mathrm{~mm}$ で、唇乳頭が発達して口唇部が見分けられること、歯

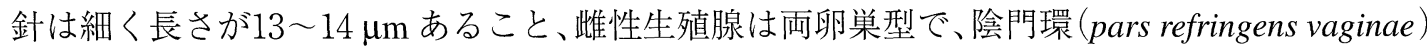
が骨化すること、直腸囊（post-rectal sac）は小さいこと、尾部が円錐形でわずかながら背側に 反ることなどで特徵付けられる。䧳性生殖腺が後卵巣型の O. occidentalis Peña Santiago \& Peralta, 1995もわが国で初めて見出されたので記載を行った。 